Universidad

Complutense

Documentos de Trabajo del Departamento de Derecho

Mercantil

$2011 / 39$

(mayo) 2011

\title{
REFINANCING, DEBT FOR EQUITY AGREEMENTS AND TAKEOVER BIDS UNDER SPANISH LAW
}

FRANCISCO JAVIER ARIAS VARONA

Profesor Titular de Derecho Mercantil

Universidad Rey Juan Carlos

Ponencia presentada en VIII Seminario Harvard-Complutense ("Mergers and acquisitions in the context of the financial crisis") celebrado en la Universidad de Harvard entre el 27 y 30 de septiembre de 2010 con el patrocinio de Allen\&Overy, Banco Santander, Ilustre Colegio Notarial de Madrid, Ilustre Colegio de Registradores de España, J\&A Garrigues.

E-mail autor: franciscojavier.arias@urjc.es http://www.ucm.es/centros/webs/d321/

Documento depositado en el archivo institucional EPrints Complutense http://www.ucm.es/eprints

Copyright (c) 2011 por el autor 


\author{
FCO. JAVIER ARIAS VARONA \\ Professor of Commercial Law, Universidad Rey Juan Carlos
}

\begin{abstract}
This paper focuses on the connection between agreed solutions to the insolvency of listed companies implying changes in corporate control and the rules governing takeover bids. The solution to insolvency problems sometimes leads to a change in corporate control, namely when the solution involves modifying the capital structure of the company. In such cases, when the insolvent entity is a listed company, takeover bid regulation must be taken into account, as it can render the operation impossible or economically useless, if the change in control of the company must be accompanied by a mandatory takeover bid. As seen below, there are specific rules governing these scenarios. This paper reviews how Spanish Law deals with the situation, although certain general ideas will be initially provided as an introduction to the problem.
\end{abstract}

KEYWORDS: Debt for equity swap, takeover bid, mandatory takeoverbid exemption, insolvency, companies in distress.

1 This paper is the result of my participation in the VIII Harvard-Complutense Seminar ("Mergers and acquisitions in the context of the financial crisis"), that took place between 27 and 30 september 2010 at the Harvard Law School in the context of the collaboration between Harvard University and the Real Colegio Complutense in Harvard (http://www.realcolegiocomplutense.harvard.edu/) and that was sponsored by Allen\&Overy, Banco Santander, Ilustre Colegio Notarial de Madrid, Ilustre Colegio de Registradores de España, J\&A Garrigues.

The study has been conducted under the Research Project DER2009-11269 of the Spanish Ministry of Science and Innovation. 
REFINANCING, DEBT FOR EQUITY AGREEMENTS AND TAKEOVER BIDS UNDER SPANISH LAW

FCO. JAVIER ARIAS VARONA

Professor of Commercial Law, Universidad Rey Juan Carlos

I. REFINANCING, INSOLVENCY AND CORPORATE CONTROL.................. 1

A. SOLUTIONS FOR COMPANIES IN DISTRESS AS A SOURCE OF CHANGES

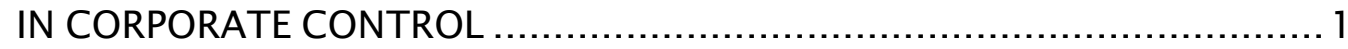

B. TAKEOVER BIDS AND CHANGE IN CONTROL IN THE CONTEXT OF

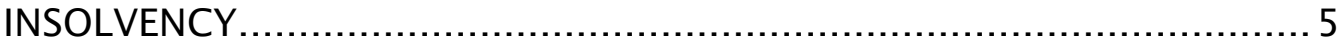

II. DEBT FOR EQUITY AGREEMENTS, GAINING OF CONTROL AND

TAKEOVER BID EXEMPTION UNDER SPANISH LAW............................ 8

A. CONTROL MUST FOLLOW A DEBT FOR EQUITY AGREEMENT ............. 9

B. SOLUTION FOR COMPANIES IN DISTRESS …............................ 13

C. NON-AUTOMATIC EXEMPTION ............................................... 17

III. CONCLUSIONS. ..................................................................... 20

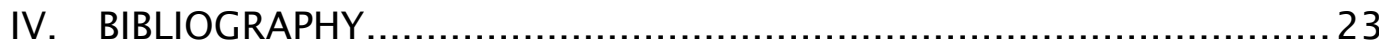




\section{REFINANCING, INSOLVENCY AND CORPORATE CONTROL.}

There are two questions that must be answered before dealing with the issue addressed by this paper. I will attempt to do so in this section. The first step is to determine whether it is possible and probable for legal or agreed solutions to solvency problems to lead to a change in corporate control. Secondly, I will attempt to answer the question of whether the rules governing the corporate control of listed companies and takeover bids should remain the same, even if the change of control takes place as an effect of the solution to the financial or solvency problems of the company involved.

\section{A. SOLUTIONS FOR COMPANIES IN DISTRESS AS A SOURCE OF CHANGES IN CORPORATE CONTROL}

Can a change in corporate control take place in the context of a financial crisis, as an effect of the situation or its possible solutions? The answer is undoubtedly positive. In fact, it can come as a result of specific rules governing certain kinds of debtors or from voluntary agreements.

There are markets with special procedures for the solvency problems of their participants, which can lead to a change in control of the companies affected. The clearest example is the specific rules governing financial markets. In the case of banks, before the crisis leads to a situation in which the only solution is insolvency law, which would be highly problematic, not only for debtors or creditors, but also for the financial sector itself, it is reasonable to establish specific procedures to avoid the situation, whenever possible. Under such procedures, rules giving certain Public Authorities the power to change who is managing the companies are common. In Spain, the laws governing banks in crisis even grant the Bank of Spain the power to change a Board of Directors (see arts. 31 and 36 of Ley 26/1988, de 29 de julio, sobre Disciplina e Intervención de las Entidades de Crédito -Act 26/1988, dated 29 July on Discipline and Intervention in Credit Entities-, 
which provides for the replacing of directors for persons appointed by the Bank of Spain in cases in which the situation is so serious that it endangers the liquidity or even the solvency of the bank, amongst others). Similar provisions can be found in other markets, i.e. insurance or investment companies.

Special provisions are not the only scenarios that can lead to a change in corporate control in the context of a financial crisis. Particular agreements to end solvency problems are a common source of such changes. It is clear that certain agreed solutions for distressed debtors can imply changes in whom is controlling the company, namely when the agreement includes changes to the legal capital structure. The clearest example of this situation is when a financial crisis is solved by the entry of new investors as shareholders or by the increase of the capital held by shareholders making a capital contribution. At times, the lack of assets to cover company debts is solved by a new supply of equity, which leads to an increase in the legal capital of the company as a result of the new shares that must be issued in exchange. In such cases, the legal capital structure may change as a result of the entry of new investors or an increase in the holdings of existing shareholders. It is obvious that the change can have an impact on the control of the company. Such would be the case when the new shareholders' capital represents more than $50 \%$ of the total, or when previous shareholders with a lower share end up owning 50\% after the transaction. This effect can take place not only after a new contribution of equity, but also when creditors agree to change their position in a debt-for-equity swap agreement. Additionally, the effects can result from stand alone agreements or from a wider restructuring agreement including such operations (i.e., sale or liquidation of part of the company's businesses, plus a new supply of equity or debt for equity swap agreements).

These operations that typically lead to a change in corporate control are thus clearly possible in strictly theoretical terms. It should here be considered whether or not the agreements are possible under Spanish law as a solution to a company's solvency problems, either as a pre-insolvency workout or as a voluntary agreement under insolvency proceedings. 
The preference for out of court solutions, via an agreement between the distressed debtor and some of its creditors in an attempt to solve its liquidity or solvency problems is well known: they are shorter, less expensive and avoid potentially harmful publicity ${ }^{2}$. These reasons remain the same if the agreement indirectly leads to a change in corporate control, because of the solutions provided to the debtor. In general terms, there can be no objections to such an agreement. The out of court alternative offered by the creditors or the debtor may include provisions resulting in a change in the control of the company, such as those mentioned above. Furthermore, they normally form part of such agreements. However, the existence of general rules governing the agreements (pre-insolvency refinancing or restructuring agreements) can seriously affect their use and how the parties design them.

The Spanish Insolvency Act (Ley 22/2003, de 9 de Julio, Concursal, hereinafter, "LC") provides for such agreements, setting out the conditions under which they are protected against rescission resulting from fraudulent transfer (Additional Provision 4, LC, hereinafter "DA 4") ${ }^{3}$. Even with a limited scope of application, the rules play a relevant role, as they act as an incentive or disincentive for the parties to decide whether to reach an agreement before bankruptcy or under insolvency proceedings. It therefore has to be determined whether agreements with this purpose or effect (change in company control by means of a capital increase to allow an input of equity, for instance) will be covered by the special protection. If the answer is affirmative, the conditions required to benefit from said protection will be relevant and the parties will probably tend to design agreements and the negotiation process in order to comply with them.

${ }^{2}$ See, amongst others in the Spanish legal doctrine, PULGAR, 2008, $1 \mathrm{ff}$.

${ }^{3}$ One of the main features of DA4 LC is its limited scope of application, as it focuses only on the protection of this type of agreement against rescission, leaving out many of the other problems arising (automatic stay effects, how creditors who are not part of the agreement might be affected by its provisions, etc.), see GARCIA CRUCES, 19; GUTIERREZ GILSANZ, 2010, 656. The expected reform of the law, even retaining the DA4, is expected to deal with these problems from a broader perspective, as in other countries such as France or Italy. 
The rule regarding refinancing agreements prior to bankruptcy, when certain conditions are met, protects this kind of agreement from the risk of rescission resulting from fraudulent transfer under arts. $71 \mathrm{ff}$. LC. One of the conditions is that the agreement result in a significant increase in the credit available to the company ("ampliación significativa del crédito disponible") or the modification of obligations by way of substitution or the extension of deadlines ("modificación de sus obligaciones, bien mediante la prórroga de su plazo de vencimiento, bien mediante el establecimiento de otras contraídas en sustitución de aquéllas"). The question, then, is whether these concepts embrace agreements such as debt for equity swaps or capital increases with supply of new equity. Although disputed ${ }^{4}$ and depending ultimately on the particular provisions of each particular agreement, I believe that at least some agreements of this kind should fall under the scope of DA 4 of the LC. If creditors agree to exchange their credit for shares, for instance, the debt is transformed into equity and thus leads to an improvement in the debtor's financial situation. Even if the provision is strictly construed (there would be no increase in credit, as equity is also a debt to shareholders), in my opinion there is little doubt that the agreement will fit into the scope of DA 4 of the LC. It should be seen as a substitution of the previous obligations, with the effect of improving the company's financial situation. These agreements must comply with certain conditions to benefit from the special protection against rescission in the event of subsequent insolvency of the company. They are mainly formal: (a) a viability plan is required; (b) at least three fifths of the debt must agree to the agreement, (c) a report must be submitted by an independent expert appointed by the Registry and (d) the agreement must be executed as a public deed. A full analysis of these conditions will not be made, as it is not the main subject of this paper. It should be noted, however, that the protection will act as an incentive for the parties to meet their conditions. As mentioned above, we must expect DA 4 LC to influence the way the parties involved design the agreement and the negotiation process.

${ }^{4}$ See GARCIA CRUCES, 24, claiming that structural modifications like debt for equity and consequent increases in legal capital are not covered by DA4 LC. 
Similar considerations may apply to agreements reached during procedure as a solution. It must be determined whether insolvency law allows the clauses as valid content of the agreement (i.e. entry of new shareholders by means of an equity contribution, debt for equity agreements, mergers, etc.) and, in such case, under what conditions. The question arises in Spanish Law, as there are several rules setting limits on what can be agreed in a voluntary agreement during insolvency. This is the purpose of art. 100 LC, which serves as an instrument to prevent certain well-known abuse of the repealed law. The rule, in any event, allows voluntary agreements partially containing pacts of structural modification - mergers or debt for equity and consequent capital increase. Therefore, there is no doubt as to the availability of these instruments during insolvency proceedings, although it should be noted that a number of problems arise in such operations, due to the lack of coordination between Insolvency and Company Law ${ }^{5}$. Furthermore, the basic rule governing the content of voluntary agreements in insolvency proceedings is the freedom of contract, thus any content that is not strictly forbidden must be considered as allowed. Accordingly, not only mergers or debt for equity operations, which are strictly mentioned as allowed, but also any other pact that could lead to a change of control could validly form part of the agreement. In this regard, even the possible existence of steering committees might question the control of the company, depending on the powers given to the committee.

\section{B. TAKEOVER BIDS AND CHANGE IN CONTROL IN THE CONTEXT OF INSOLVENCY}

To fully understand why this is an issue, it is necessary to recall certain basic features of takeover bids and, in particular, those that are mandatory. It is well known that the gaining of control requires a premium to

\footnotetext{
${ }^{5}$ See, in general, debt for equity as content of voluntary agreements in insolvency proceedings, GUTIERREZ GILSANZ, A. (2009).

There are several studies on the connection between Insolvency and Company Law in the context of structural modifications as a solution, in part, to the solvency problems of a company. All of them highlight the problems resulting from a lack of coordination. See for all PULGAR, 2009, 735.
} 
be paid to the seller, as market prices do not reflect the value of control itself. Without bearing in mind other purposes, mandatory takeover bids constitute the instrument created to guarantee that all the shareholders of a listed company have the right to a share in the control premium, i.e., the premium paid for the shares carrying the power to control the targeted company. It refers ultimately to the equitable treatment of shareholders as such and as investors in a listed company ${ }^{6}$. These considerations play an important role in understanding why the rules requiring mandatory takeover bids may need to be adapted to situations in which control is gained because of a legal or agreed solution to the solvency problems of a listed company. The main reason why these situations are considered as exceptional and which explain the differences in the legal regime governing takeover bids is how the control premium works in such cases. In distressed companies, there may be no control premium or, in many cases, it will be negative, as the new controllers will have to bear the restructuring costs and eliminate losses for the company to survive. As an additional reason, sometimes there could be an interest worthier of protection than that of individual investors, namely the general interest in the company surviving (jobs, market stability, etc.). As a mandatory takeover bid will probably increase the cost of the operation, it could compromise the solution to the company's solvency problems. This being so, the interest in promoting a solution helps to explain why takeover bids rules must be adapted ${ }^{7}$.

One possible way of adapting the rules involves the concept of equitable price. It is well known that the EU Directive on takeover bids (Dir 2004/25/EC of the European Parliament and of the Council of 21 april 2004 on takeover bids) requires Member State national legislation to ensure a bid is made at an equitable price in mandatory takeover bids (art. 5). Equitable price is a protection for shareholders that is necessary in a system in which

${ }^{6}$ For a recent broader explanation of these principles in the context of takeover bid regulation, see RECALDE, 2010, $27 \mathrm{ff}$. and SANCHEZ CALERO, 2009, 33. Also see a more skeptical view in PAZ-ARES, 2002a y 2002 b.

7 See SANCHEZ CALERO, 2009, 196: the reason is that under these circumstances, the mandatory takeover rule will be less favorable for minority shareholders. Similar considerations in TAPIA HERMIDA/ALONSO LEDESMA/RODRÍGUEZ MARTÍNEZ, 2009, 256. 
mandatory bids can me made after gaining control and, under the EU Directive, should be the highest stock price in a defined period of time before the bid, which can range from 6 to 12 months, depending on the Member State concerned (see art. 5.4, which closely follows the terms of rule 9.5 of the British Takeover Code regarding the consideration that should be offered). If probable that the control premium is negative or when there are interests worthier of protection than those relating to the shareholders, a way of promoting a solution, even if it leads to a change in control of the company, is to decrease the cost of the operation if a takeover bid is still mandatory. One way to do so is to adapt the rule on equitable price. A takeover bid must be made anyway, but the cost will be lower. This is the reason why the Directive allows national legislation to adapt the equitable price rule "in order to enable a firm in difficulty to be rescued". Ultimately, it depends on the Member State to allow the supervisor to reduce the price in this regard, but it is a expressly accepted possibility in some countries, including Spain (see art. 9.4, f) of Real Decreto 1066/2007, de 27 julio, Royal Decree 1066/2007, dated 27 July, hereinafter RDOPAS-) ${ }^{8}$.

A second alternative is to dispense with the mandatory nature of the takeover bid in situations relating to the company's financial problems. This exemption is not included in the EU Directive, but is a possibility offered to legislators. In fact, exceptions to the mandatory takeover bid are common and it would therefore only require the including of a provision regarding solvency or financial problems as grounds for the exception. Spanish law on takeover bids is a good example. The RDOPAS includes an article on exceptions to the rules on takeover bids in different circumstances. There are two different categories of exceptions, the so-called "dispensas" (dispensation) and "excepciones" (exemptions). The difference is that exemptions do not require the supervisor (CNMV) to act in any way, as their conditions are expressly defined in the RDOPAS (see art. 8 RDOPAS). Dispensation, however, occurs on a case-by-case basis and requires an act to be performed by the CNMV. It could therefore be said that dispensation is an

${ }^{8}$ On equitable price and its adaptation see, amongst others, FERNANDEZ DEL POZO, 2010a and 2010b. 
instrument that grants exemption from an actual obligation, whereas in an exemption, there is no obligation to make a takeover bid when the requirements are met $^{9}$. According to this alternative, Spanish law contains several exemptions covering the financial or solvency problems of a company as grounds for excluding mandatory takeover bids. It could be debatable whether they are exemptions by nature or rather dispensations, however the RDOPAS excludes a mandatory takeover bid when control is gained as a result of the law regarding financial institution receivership (see art. 8 a) RDOPAS, in connection with Ley 26/1988, de 29 de julio, sobre Disciplina e Intervención de las Entidades de Crédito, previously mentioned as an example of these procedures) or in debt for equity agreements entered into by companies in distress (art. $8 \mathrm{~d}$ ) RDOPAS).

\section{DEBT FOR EQUITY AGREEMENTS, GAINING OF CONTROL AND TAKEOVER BID EXEMPTION UNDER SPANISH LAW.}

This second part of this paper focuses on the exemption of mandatory takeover bids set forth in art. 8d) RDOPAS after control is gained in the listed company by way of a debt for equity agreement serving as an instrument to ensure the survival of a company in distress. It therefore does not cover either the exemption regarding financial institution receivership (and similar institutions) or other kind of agreements that may result in a change in control. In the first case, because the main point of interest in such cases is to study the specific receivership regulation, which has been done in other studies already published or underway ${ }^{10}$. In the second case, because there is no specific exemption for such agreements and a takeover bid would be mandatory even if they served as an instrument for solving the company's

${ }^{9}$ See SENENT, 2010 and SANCHEZ CALERO 2009, 190.

${ }^{10}$ Other speakers in the VIII Harvard-Complutense Seminar studied these special institutions, deeply modified in the latest times, either under the Spanish law or from a wider perspective. Some of their work is already available as working papers where the reader could find a deeper analysis of the main points of these instruments facing the problem of financial institution distress (see MARTINEZ ROSADO, 2010). Some published works also give a good insight on these institutions and connect them with the issue of this paper, see lately LEON SANZ, 2010, $184 \mathrm{ff}$. 
financial problems. In these cases, it should be noted again that the mandatory takeover bid legal provision will act as a disincentive, as it will increase the cost of the operation and may render it impossible, even if there is an adjustment of the equitable price that must be offered to the shareholders. In addition to cost, the uncertainty resulting from the fact that the adjustment is subsequent to the operation itself plays an important role, ultimately depending on the decision of the supervisor, which will logically follow the agreement. As the whole refinancing/ restructuring operation will depend upon the adjustment, not being sure a priori that it will be authorized, it serves as a substantial disincentive for the parties to decide to use this kind of agreement.

Spanish law dispenses with the obligation to make a mandatory takeover bid in operations where control is gained as a result of a debt for equity agreement reached to ensure the long term recovery of companies whose financial survival is under a serious and imminent threat. This kind of provision is not new to Spanish law. A similar exemption was already present in the 1991 RD, after its amendment by RD 432/2003, dated 11 April. Although there are relevant differences, which will be considered below, art. 4 of RD 1197/1991 (now repealed) also dispensed with the obligation to make a mandatory takeover bid whenever resulting from a voluntary agreement of debt exchanged for stock during insolvency proceedings. One of the main features of the current Spanish system is that the exemption is not automatic, as it requires a series of poorly defined conditions, evaluated by the supervisor. Consequently, exemption is subject to the due authorization of the CNMV. I will now explain the main features of the rule, starting with the operation referred to, followed by how it must be linked to the solution for a company in distress and ending with the non automatic nature of the exemption.

\section{A. CONTROL MUST FOLLOW A DEBT FOR EQUITY AGREEMENT}


I have already pointed out that control can be gained by many ways in agreements regarding the solution of company financial problems. However, the RDOPAS limits the scope of application of the exemption rule to only one of such agreements: when control is gained as a result of a debt for stock agreement. It must be clear when control is supposed to be gained and what operations fall under the category of debt for equity, for the purposes of art. 8d) RDOPAS.

The exemption does not define when control is gained and thus makes a takeover bid mandatory. Being an exception to the basic rule of mandatory takeover bids, the definition must be sought where the basic rule is given: art. 3 RDOPAS. This article uses two indicators of the existence of control: the holding of a voting rights share equal to or exceeding $30 \%$ or, if less, the appointing of a number of directors that, together with the directors previously appointed within the 24 months subsequent to acquiring the share represents more than half the company's board of directors. This control can be gained by just one person holding the voting rights share or by several persons acting in concert. In addition to these indicators, it must be specifically considered that the takeover bid is mandatory if and only if control has been acquired by any of three ways ${ }^{11}$ : (a) the acquisition of securities granting voting rights in the company or the acquisition of voting rights resulting from usufruct, pledge or a contractual relationship; (b) agreements reached with other shareholders; and (c) the gaining of control of another company, even if unlisted, that leads to a share with voting rights in a listed company equal to the percentage set forth in art. 3 RDOPAS (see art. 7 RDOPAS) ${ }^{12}$.

\footnotetext{
1 See FARRANDO, 2010, 60

12 Mandatory takeover bid follows any change in control, being irrelevant if it is direct or indirect (i.e., as a consequence of gaining the control of a controlling company). This difference, however, plays an important role for the exemption, as legal doctrine suggests that, out of the case of financial institutions in which the exemption applies not only for the company controlled but to any indirect change of control in companies controlled by the financial institution (see art. 8a) RDOPAS), the exemption granted by art. 8d RDOPAS will not cover indirect control gained on other listed companies after the change of control of any distressed listed company as a result of a debt for equity swap agreement. The difference is explained as a consequence of the stronger public interest present in the solution for solvency problems of financial institutions (see LEON, 2010, $211)$.
} 
Exempt operations are those in which control comes as a result of the acquisition of securities or any other operation resulting from a debt for equity agreement, the latter taken in a broad sense, as explained below. The law therefore limits the exemption from having to make a takeover bid to the gaining of control from a specific operation. The way in which control is gained is irrelevant, provided it comes as a result of a debt for equity agreement. How to understand this concept and whether control must only result from the agreement is crucial to fully appreciating the extent of the exemption.

Debt for equity swaps are a very common tool in debt restructuring, both in pre-bankruptcy solutions as well as in insolvency proceedings. In strictly financial terms, they imply a debt being exchanged for a certain amount of equity. The issue of new shares is not required, as it can be made using the alternative of increasing nominal value, but in any case, an increase in the legal capital must accompany the operation. Under the Spanish law, such operations must be pursuant to the general rules governing capital increases (arts. 295 ff. of RD Legislativo 1/2010, de 2 de Julio, por el que se aprueba el Texto Refundido de la Ley de Sociedades de Capital -Royal Legislative Decree 1/2010, dated 2 July, Limited Liabilities Company Act-, [hereinafter, "LSC"]) and those regarding shares for debt exchange (art. 301 LSC). It is important to clarify that they can result from a specific debt for equity exchange agreement or simply be the effect of how the debt itself was created. There are cases in which the debt exchanged for stock were bonds that, at the time that they were issued, were thought to be exchangeable for shares upon the request of the owner at a particular time (typically, when the bond had to be repaid). The difference can play an important role under Spanish law. As we have already observed, the rules governing prebankruptcy workouts protection against rescission require the agreement to modify "obligations by replacing them for new obligations or extending the deadline". It might be thought that in such cases, the condition is not met as 
the obligation seems to have remained intact under the same terms (bond for share exchange must meet the conditions upon issue, art. 302 LSC) ${ }^{13}$.

The wording of art. 8 d) RDOPAS does not support a strict interpretation of the operations covered by the exemption. Its provisions do not strictly refer to the typical corporate law capital increase by way of a debt for shares exchange and covers all operations in which a debt is transformed into shares, resulting in the gaining of control. The exemption will thus apply when the control is acquired, for instance, after foreclosure of share pledges or in cases of share assignment ${ }^{14}$. In addition, control must not result only from a debt for equity exchange. If it is the result of a combination of different factors, one of them being the debt for equity agreement, exemption will also apply. It is doubtful, however, whether the gaining of control resulting from a complex operation will benefit from the exemption, without considering the importance of the debt for equity agreement in order to gain such control. Although I do not believe it necessary for control to be gained only as a result of a debt for equity operation, its role must be more than insignificant to preserve the exceptional nature of the exemption. If not, a simple one share exchange for an insignificant debt would suffice to benefit from the exemption.

It must be highlighted that the debt exchanged for equity could have been previously transferred, allowing the exemption to be applied in complex operations where, for instance, a debt is transferred to a special purpose company or to one of the previous shareholders ${ }^{15}$. This was impossible under the 2003 Spanish takeover bids regulation, as it required creditors converted into the controlling shareholder to have been the original creditor, the exemption therefore not being possible if the debt was previously transferred to a third party ${ }^{16}$. This broadening of the scope of

${ }^{13}$ See TAPIA, 2010, 112

${ }^{14}$ LEON SANZ, 2010, 209.

${ }^{15}$ LEON SANZ, 2010, 209

${ }^{16}$ Repealed art. 4 RD1197/1991 read "provided the creditor was the original one and not because of an assignment of credit". 
application of the exemption to mandatory takeover bids seems somehow incoherent with how insolvency law deals with debt transfers after insolvency (for instance, the LC does not grant assignees the right to vote at a creditors' meeting to decide upon a voluntary agreement in insolvency proceedings, in an obvious attempt to prevent a voting rights market, for fear of fraudulent transactions, see art. $122 \mathrm{LC}^{17}$ ).

\section{B. SOLUTION FOR COMPANIES IN DISTRESS}

A second condition to be met for the exemption to apply is that the debt for equity leading to the gaining of control be a solution for a company in distress. Art. 8 d) RDOPAS was deliberately conceived with a very broad scope of application in this regard. According to the wording, the exemption applies to any listed company whose "financial viability is in serious and imminent danger, even if not subject to insolvency proceedings", provided the operation is "designed to ensure financial recovery in the long term". The law clearly requires two different conditions that must be considered separately.

Firstly, the listed company must be under a serious and imminent danger, but not necessarily under insolvency proceedings. The legislator could have linked the situation to a specific legal concept, such as that of insolvency, or to a specific legal situation, such as insolvency proceedings. In fact, that was the choice of the repealed 1991 Royal Decree, after the amendment of 2003. The exemption applied only to agreements reached in insolvency proceedings, thus requiring the company to be subject to such proceedings. However, the RDOPAS 2007 uses a different approach, probably because a stringent scope of application could render the exemption useless in many cases. Many problems arise from a wider definition, but it

17 The proposed reform of the Spanish Insolvency Law, now being discussed in the Congress (the latest version when this paper was finished could be find here: http://www.congreso.es/public_oficiales/L9/CONG/BOCG/A/A_119-01.PDF), will allow credits' assignees to vote at the creditors' meeting if the law is finally passed without change in this regard. The new art. 122 LC will limit, however, this right to any assignee being an "institution under financial supervision", what seems to be read as a bank or equivalent. Any other assignee will still not be able to vote if the wording remain the same and the law is finally passed. 
guarantees that the exemption will apply also in situations equivalent to a voluntary agreement under insolvency proceedings. Considering the reasons for exemption of a mandatory takeover bid and the purpose of the rule ${ }^{18}$, the scope of application is linked to companies in distress. If exemption is to be granted because the control premium is negative or there are interests worthy of protection other than shareholder interests, the exemption must be given any time the situation arises. And it is clearly logical to identify the situation when the future existence of the company is threatened by a serious and imminent danger.

The exemption is intentionally disassociated to insolvency proceedings and the conditions required for such proceedings to commence. This does not mean that voluntary agreements in insolvency proceedings are not covered. If the content of the agreement includes a debt for equity swap leading to a gaining of control, the exemption will apply, provided every other condition is met, as stated above. What I mean by a disconnection between the RDOPAS and the LC is that the basic requirement for exemption must not be identified with the requirement for insolvency proceedings to commence, i.e., insolvency. Under Spanish law, the latter is defined as the impossibility for a debtor to "meet its obligations in a regular and timely manner", whether at the time or in the near future. Even if the wording used in art. 2 LC seems to be close to that of art. 8d) RDOPAS, it would be a mistake to construe the rule under the filter of insolvency law. RDOPAS also uses the word imminent, but it should not be read as equivalent to "imminent insolvency" that Spanish insolvency law borrowed from German Law. If a company foresees that it will be unable to meet its obligations in a regular and timely manner in the near future, its financial viability is clearly in danger. But it does not mean that the future existence of the company is subject to a serious and imminent danger only where it is or foresees to be in the future, unable to meet its obligations in the sense of art. 2 LC.

For the reasons indicated above, it is not possible to use the concept of current or imminent insolvency as the only reference to define the scope

${ }^{18}$ See LEON, 2010, 208 
of application of the exemption referred to in art. $8 \mathrm{~d}$ ) RDOPAS. If the law has consciously departed from the notion of insolvency, it would be a mistake to resort to legal doctrine and court interpretation of the notions used by the LC. As an undefined concept, it should be construed by reference to the purpose of the rule, bearing in mind why the exemption is granted and the clear intention of giving it a broad scope of application to cover not only legally defined situations, but rather all financial situations seriously endangering the future of the company ${ }^{19}$. As stated above, as an extraordinary repeal of the mandatory takeover rule, the exemption must also require the operation leading to a gaining of control to be the only solution or, at least, the one with lowest costs, given that the interests of shareholders must be considered ${ }^{20}$. This is ultimately the reason why the exemption is granted and the key to understanding what situations it must cover.

One of the advantages of the scope of application, as defined by art. 8 d) RDOPAS is that it is not limited to the agreements reached in insolvency proceedings. As mentioned above, a debt for equity swap leading to a change in control in a listed company can be included as part of a wider restructuring agreement to cure a company's financial problems. Such agreements are often reached outside insolvency proceedings as a way of avoiding financial and reputation costs. The exemption therefore covers these agreements and, in particular, the refinancing agreements referred to in DA4 of the Spanish LC. However, mention should here be made to the difficulties arising from the strict concept of the agreements covered by the protection afforded by DA4 LC $^{21}$ and the apparent extraordinary nature of debt for equity as content thereof ${ }^{22}$. In any case, even if the agreement does not fall within the scope of application of the DA4, it will be irrelevant for the

\footnotetext{
${ }^{19}$ Any statement in the sense indicated (serious threat to the financial situation) in an auditors' report should be considered as sufficient for the requirement stated in art. 8 d) RDOPAS to be met, see LEON, 2010, p. 208.

${ }^{20}$ LEON, 2010 , p. 208.

${ }^{21}$ The problem is a consequence of the requirements of DA4 LC (a significant increase in the credit available for the company or the modification of the obligations by replacing them for new ones or the extension of deadlines), see on page 4 .
}

${ }^{22}$ In this regard, see LEON, 2010 , p. 207. 
purposes of the exemption to a mandatory takeover bid, as the DA4 does not limit the agreements that can be validly reached, but rather those for which special protection against rescission for fraud is provided. Parties will tend to meet the conditions of the DA4, but this does not mean that there is no room outside it for agreements affected by the exemption stated in art. 8 d) RDOPAS.

The second condition is that the operation must be designed to ensure financial recovery in the long term. Once again, the rule uses an open concept linked to non-legal concepts that should be construed according to the intended purpose of the exemption. It should be observed, however, that in this case the rule adopts an intention oriented position. For obvious reasons, it would be impossible to require recovery because of the agreement, as it will be affected not only by the operation itself, but also by many other external factors (market growth, future management, etc.). It is therefore logical that the exemption must rely on the intention of the parties, which requires an analysis of whether or not the operation seeks such purpose and, in my opinion, could reasonably be achieved in the underlying situation and foreseeable evolution of the company and its business activity ${ }^{23}$. Accordingly, the special role given to the CNMV regarding the exemption is fully understandable, as independent control of compliance with requirements is necessary. If the operation is part of a refinancing agreement of the kind set forth in the DA 4 LC, there must be a report from an independent expert appointed by the Registry, playing a very relevant role in this regard. It is true that the DA4 LC uses a different time reference (short and medium term), but it would be advisable for the parties to the agreement for the independent report to also focus on the long term, in favour of the exemption.

The time reference used by art. 8 d) RDOPAS is undefined and resembles that referred to in the DA4 LC (short and medium term). Although

\footnotetext{
${ }^{23}$ Part of the legal doctrine consider necessary a viability plan analyzing the operation and how it will affect the long term recovery of the company, see TAPIA HERMIDA/ALONSO LEDESMA/RODRÍGUEZ MARTINEZ, 2009, 257
} 
there are certain standards in finance, it would probably be necessary to adopt a case-oriented approach and consider the time used for analysis by the parties, thus giving them flexibility as to the duration of the "time" reference ${ }^{24}$.

\section{NON- AUTOMATIC EXEMPTION}

Exemption from filing a mandatory takeover bid is not automatic and ultimately depends on the decision of the supervisor: the Spanish National Securities Commission (Comisión Nacional del Mercado de Valores, CNMV hereinafter $)^{25}$. The reason for this is undoubtedly that the requirements for the exemption are not a standard checklist. Some of them, as already mentioned, are defined in such a broad way that a comprehensive and independent analysis of the situation is required as to the foreseeable future, the intention of the parties and even the design of the operation itself. Amongst the alternatives (a faster and more certain procedure $v s$. a more adaptive rule), the law has chosen the more flexible rule, even though it leads to uncertainty ${ }^{26}$. As explained below, the situation could have been considered different in out of court or in voluntary agreements to insolvency proceedings, but this distinction has been clearly rejected, so the approach is exactly the same regarding the role of the CNMV in the exemption. I will attempt to briefly explain the possible consequences of the non-automatic nature of the exemption in general.

The fact that the CNMV must evaluate the requisites and decide whether to grant or refuse the exemption poses two different issues. The first is how much freedom the supervisor has in this regard. Even if a final decision must be made by the CNMV, it would be a mistake to consider it

${ }^{24}$ See a similar approach for the DA4 LC reference (short and medium terms) in GARCIA-CRUCES, 2009, 27.

${ }^{25}$ The fact that the CNMV has the power to decide and that the exemption is not automatic explains why a part of Spanish legal doctrine doubts whether it is a case of exemption or rather a dispensation (see SENENT, 2010, 364). The difference plays no role if a different approach to the categories of exceptions to mandatory takeover bids is used, see FARRANDO, 2010, $154 \mathrm{ff}$.

${ }^{26}$ See, similarly, ZURITA, 2009, 219. 
arbitrary. As stated above, the exemption conditions are defined very broadly in order to make the rule as flexible as possible. This is the reason why the exemption, unlike the others in art. 8 RDOPAS, is not automatically granted and requires evaluation by the CNMV. The supervisor must decide whether the specific situation falls under the scope and aim of the exemption, in other words, if the operation will allow the company in distress to solve its financial problems, taking into account all the information provided by the parties, which must be evaluated by the CNMV accordingly. To avoid any arbitrariness, even if not specifically stated in art. $8 \mathrm{~d}$ ) RDOPAS, the CNMV should explain the grounds for its decision, especially when the exemption is not granted.

A second issue arising from art. 8 d) RDOPAS is whether a nonautomatic exemption will affect the system's practical application. The answer is clearly positive: it will have a substantial impact. The parties engaged in this kind of agreement cannot be sure from the beginning of whether it will be eligible for the exemption, as it will ultimately depend on the evaluation made by the supervisor. Of course, they can try to meet all the conditions as set forth in art. 8 d) RDOPAS and obviously provide appropriate proof to the CNMV (for instance, by way of an independent expert's report). However, they cannot be one hundred percent sure of a positive answer from the supervisor to their request. This uncertainty will probably act as deterrence to this kind of operation for listed companies in distress, when the effect is the gaining of control, leading creditors to other alternatives where they can expect certainty in relation to financial conditions. It should not be overlooked how much an eventual mandatory takeover bid will increase the costs of the operation ${ }^{27}$. Whether or not this solution will be different depending on the scenario under which control is gained will be discussed below, however it seems clear that in the balance between a priori certainty and flexibility of the rule, plus public control to avoid abuse, Spanish law has clearly decided for the latter.

\footnotetext{
${ }^{27}$ In this regard, see SENENT, 2010, p. 365.
} 
CNMV intervention follows a specific procedure. It is obvious that the procedure commences after a request for exemption has been made by the parties to the agreement, namely by the entity acquiring control after the operation has taken place ${ }^{28}$. The Law does not require any formalities, although the application must contain all the documents evidencing compliance with the conditions under which the exemption can be granted ${ }^{29}$. There is no list of the documents that must accompany the request and the parties are relatively free to enclose those they consider appropriate, such as independent expert reports on the conditions of the agreement, the company's financial problems and how the agreement will allow the company to survive in the long term.

The CNMV has 15 days to grant exemption or refuse it and, although application is not mandatory before completing the operation, it is obviously better to do so, in order to be sure of the CNMV's position. According to the general principles of Administrative Law, if the CNMV does not provide an answer to the request in the specified time, the exemption can be taken for granted ${ }^{30}$.

Finally, it must be considered whether the option taken by Spanish Law could have been different under certain scenarios. This is a question arising mainly from the contrast between the solution adopted by RDOPAS and that of the repealed regulation. It should be said that in the previous $\mathrm{RD} / 1997$, the exemption equivalent to that set forth in art. 8 d) RDOPAS was automatic, as it was linked to an agreement in insolvency proceedings. In the now repealed art. 4 RD1197/1991, the exemption was granted for any control gained after a debt for equity agreement resulting from a voluntary agreement reached in insolvency proceedings. No further intervention by the CNMV was required; hence the exemption was automatic if the requirements were met. The different approach is clearly a consequence of the broadening of the scope of application of the rule. As an agreement can be reached

\footnotetext{
${ }^{28}$ See SANCHEZ CALERO, 2009, 196.

${ }^{29}$ See SENENT, 2010 , p. 365.

${ }^{30}$ See FARRANDO, 2010, 175.
} 
outside court, there is no independent control of company's situation and whether or not it is truly in distress. It must not be overlooked that this is the starting point for exemption from filing a takeover bid. The insolvency procedure and court control is thus replaced by the control of the CNMV.

In accordance with the above ideas, some authors consider that another option was available to Spanish legislators, who could have differentiated between out of court and insolvency agreements. For the former, CNMV control would be reasonable, as explained. For the second, however, the compromise between flexibility and certainty could have been decided in favour of the latter. The idea is that whenever an agreement is reached during insolvency proceedings, no further controls are needed. Firstly, because the procedure requires insolvency to be opened, which is a concept included in art. 8 d) RDOPAS (economical viability under a serious and imminent threat), which must pass court control. Secondly, the presence of an insolvency court guarantees protection of all the parties included and an analysis of the role that the agreement will play in the future survival of the company. The further intervention of the CNMV is not only unnecessary, but also creates certain coordination problems in the proceedings. It should be mentioned that such intervention will render almost impossible a voluntary agreement of this kind without previous exemption, as under Spanish law, a conditioned agreement is forbidden by insolvency law (see art. 100 LC). Legal doctrine suggests that Spanish law should have set up two different conditions for the exemption, making evaluation by the CNMV necessary only for out of court agreements ${ }^{31}$.

\section{CONCLUSIONS.}

Changes in corporate control often take place in the context of a financial crisis of a company, as an effect of the situation or its possible solutions. In some markets, namely financial markets, the special procedures can lead to a change in control of the companies affected. Furthermore, certain agreements designed to end with the solvency problems of a company can

${ }^{31}$ See ZURITA, 219, SENENT, 2010, 365 
be a source of such changes. This agreements can be reached whether before any insolvency proceeding is opened or into it, once it has been opened. One of the clearest examples are debt for equity swaps, in which debt is exchanged for shares, so previous creditors are transformed into shareholders, or the capital shared by shareholders is increased as a result of the operation. In those situations involving public listed companies, it raises the question of whether the rules governing takeover bids must be adapted, as they can compromise this way of solving solvency problems of these companies. This is the case where a mandatory takeover bid must follow the change of control, as it would increase the cost of the operation making it unattractive. There are special rules under Spanish law exempting the mandatory takeover bid for any debt for equity agreement that serves as an instrument to ensure the survival of a company in distress and leads to a change of control of the company. The rule, set forth in art. 8d) RDOPAS requires two different conditions.

First of all, the control gain must follow a debt for equity agreement. The control gain is not specially defined, so it derives of the holding of a voting rights share equal or exceeding $30 \%$ or, if less, of the appointing of a number of directors that, together with the directors previously appointed within the 24 months subsequent to acquiring the share represents more than half the company's board of directors. More relevant, the control must result of a debt for equity swap, what means that the way it is gained is irrelevant as long as it is a consequence of that kind of agreement. Although it will not cover other kind of agreements that can derive into a change in control, under Spanish law this is not referred only to the typical corporate law capital increase by way of a debt for shares exchange, but covers also any operation in which a debt is transformed into shares, resulting in the gaining of control, i.e., when the control is acquired, for instance, after foreclosure of share pledges or in cases of share assignment. It is not necessary that the control is gained only because of the agreement, but its role must not be insignificant to preserve the exceptional nature of the provision. There is some incoherence in the fact that the exemption will apply if the debt exchanged for equity was previously transferred, as Spanish insolvency law does not seem favourable to these situations. 
Secondly, the agreement must be a solution for companies in distress. It is not necessary that the company is under an insolvency proceeding, but its financial viability must in serious and imminent danger. Although such a wide concept puts problems, it guarantees the granting of exemption in any situation equivalent to voluntary agreements in insolvency. As the concept is disassociated of the conditions required for insolvency procedure to be opened it should not be construed under the legal doctrine and court interpretation of the notions used by the Spanish Insolvency Law. The wider scope of application of the art. 8d) RDOPAS has the advantage that it covers any agreement, provided the financial situation of the company endangers seriously its future viability. Preinsolvency workouts coud benefit, then, of the exemption set forth in art. 8d). As an additional requirement, the operation must be designed to ensure financial recovery in the long term. This requirement relies on the intention of the parties, but must be tested by the supervisor according to the information given by the parties, the underlying situation and the foreseeable evolution of the company and its business activity. The time reference should be evaluated according to the time used for analysis by the parties.

The exemption is not automatic and depends on the decision of the Spanish supervisor (CNMV). This is a consequence of how broadly the requirements are defined, making it necessary an independent analysis of the situation. This decision must not be arbitrary, being therefore necessary that the CNMV explain the grounds, especially when it is refused. The uncertainty deriving of this non-automatic nature will probably act as deterrence for this kind of operations for listed companies, but it seems that Spanish legislators have opted for a more flexible rule, plus public control to avoid abuses. The procedure is the same even if the agreement is reached in an insolvency procedure, although in this situation there is some control by the insolvency court of the situation of the company and the content of the agreement and a different solution could have been considered to avoid the coordination problems that inevitably arises in these scenarios. 


\section{BIBLIOGRAPHY}

FERnÁndez del Pozo, L. (2010a), "El precio equitativo en una OPA (I): consideraciones generales", in Juste Mencía, J. / ReCAlde CAstells, R. (dirs.), Derecho de OPAS. Estudio sistematico del régimen de las Ofertas Públicas de Adquisición en el Derecho español, Valencia, 2010, 245ff.

FernÁNDEZ Del Pozo, L. (2010b), "El precio equitativo en una OPA (II): la regulación en el RDOPAS", in JUSTE MENCíA, J. / ReCALDE CASTELLS, R. (dirs.), Derecho de OPAS. Estudio sistematico del régimen de las Ofertas Públicas de Adquisición en el Derecho español, Valencia, 2010, $279 \mathrm{ff}$.

FARRANDO Miguel, I. (2010), "Los indicadores de la adquisición de control y el deber de formular una OPA obligatoria", in JUSTE MENCíA, J. / RECALDE CASTELLS, R. (dirs.), Derecho de OPAS. Estudio sistematico del régimen de las Ofertas Públicas de Adquisición en el Derecho español, Valencia, 2010, 59ff.

García-Cruces GonzÁlez, J.C. / López SÁnChez, J. (2009), La reforma de la Ley Concursal. Una primera lectura del Real Decreto - Ley 3/2009, Cizur Menor, 2009.

Gutiérrez Gilsanz, A., “. "El consentimiento en el convenio mediante conversión de créditos en acciones, participaciones o cuotas sociales", Revista de Derecho concursal y Paraconcursal, 10, 2009, $279 \mathrm{ff} .$.

LEÓN SANZ, F.J. (2010), "La crisis de las sociedades cotizadas y el regimen de OPAS", in Juste Mencía, J. / ReCalde CAStells, R. (dirs.), Derecho de OPAS. Estudio sistematico del régimen de las Ofertas Públicas de Adquisición en el Derecho español, Valencia, 2010, $183 \mathrm{ff}$.

MARTínez RosAdo, J., (2010), “Fusiones y otros medios de reestructuración como medio de evitar el concurso de una entidad de crédito", Working Paper, available

at

http://eprints.ucm.es/11877/1/COMUNICACIÓN_HARVARD_2010_javier_ma rt\%C3\%ADnez_rosado.pdf.

PAZ-ARES, C., (2002a), La reforma de la OPA y el espejismo de la prima de control (I)", Expansión, 8 de octubre de 2002, available at 
http://www.uam.es/centros/derecho/privado/mercanti/profesores/generalcp azares.html

PAZ-ARES, C., (2002b), La reforma de la OPA y el espejismo de la prima de control (II)", Expansión, 16 de octubre de 2002, available at http://www.uam.es/centros/derecho/privado/mercanti/investigacion/cpa\%2 0-\%200PASyPrimas2.pdf

Pulgar Ezquerra, J. (2009), "Modificaciones estructurales de sociedades en liquidación y en situación concursal", in RODRícuez ARTIGAS / ALONSO UREBA / Fernández de la Gándara / Velasco San Pedro / Quijano González / Esteban VELASCO, Modificaciones estructurales de las sociedades mercantiles, T. II, Cizur Menor, 2009, 729 ff.

Pulgar Ezquerra, J. (2008), "Refinanciaciones de deuda y concurso de acreedores: la ausencia de "escudos protectors" y el fraude del art. 10 de la Ley del Mercado Hipotecario", Diario La Ley, 6963, 9 de junio de 2008, 1 ff

Sánchez Calero, F. (2009), Ofertas Públicas de Adquisición de Acciones (OPAS), Cizur Menor, 2009.

SeneNT Martí, S., "Refinanciación de deuda y capitalización concursal de créditos en el marco de las exclusions legales de ofertas públicas de adquisición de acciones", Revista de Derecho Concursal y Paraconcursal, 2010, 12, 357ff.

Tapia Hermida, A. / Alonso ledesma, C. / Rodrícuez Martínez, I. (2009), "Opas obligatorias, OPAs con finalidades específicas y OPAs voluntarias", in BENEYTO Pérez, J.M. / LARGo GIL R., Régimen jurídico de las Ofertas Públicas de Adquisición (OPAS), Barcelona, 2009, $161 \mathrm{ff}$.

TAPIA HeRmidA, A., (2010), "La compensación de créditos mediante su conversión en acciones como medida de refinanciación de las sociedades cotizadas y la obligación de formular una OPA", Revista de Derecho Concursal y Paraconcursal, 2010, 13, 107ff.

ZuRIta y Sáenz de NaVARRete (2009), "Artículo 8. Supuestos excluidos de la oferta obligatoria cuando se alcanza el control", in GARCíA DE ENTERRía, J. / ZuRITA SÁenz de NAVARRETE, J., Comentario sistemático del RD 1066/2007, de 27 de Julio, Cizur Menor, 2009, $210 \mathrm{ff}$. 